\title{
Effects of Different Levels of Fermented Oat on Growth Performance, Nutrient Digestibility, Diarrhea Incidence, Fecal Microorganisms and Emission Gas in Weaned Pigs
}

\author{
J. H. Cho ${ }^{1}$ \& I. H. Kim ${ }^{1}$ \\ ${ }^{1}$ Department of Animal Resource \& Science, Dankook University, Cheonan, Choongnam, South Korea \\ Correspondence: Prof. I. H. Kim, Department of Animal Resource \& Science, Dankook University, Cheonan, \\ Choongnam, South Korea. Tel: 82-41-550-3652. E-mail: inhokim@dankook.ac.kr
}

Received: June 25, 2012 Accepted: July 20, 2012 Online Published: October 12, 2012

doi:10.5539/jas.v4n11p40

URL: http://dx.doi.org/10.5539/jas.v4n11p40

\begin{abstract}
This study was conducted to investigate the effects of different levels of fermented oat meal on growth performance, diarrhea incidence, fecal microorganisms, and emission gas in weaned pigs. A total of 80 crossbred piglets $(7.31 \pm 0.24 \mathrm{~kg})$ weaned at 21 days of age were assigned to treatments in a randomized complete block design based on the initial body weight (BW). This experiment included 2 phases. In the first phase (from 0 to 21 d), there were 5 treatments: T1 (15\% nature oat), T2 (3.7\% fermented oat $+11.3 \%$ nature oat $),$ T3 $(7.5 \%$ fermented oat $+7.5 \%$ nature oat), T4 $(11.3 \%$ fermented oat $+3.7 \%$ nature oat $)$, T5 (15\% fermented oat). In the second phase (from 21 to $35 \mathrm{~d}$ ): T1 ( $7 \%$ nature oat), T2 (1.75\% fermented oat $+5.25 \%$ nature oat), T3 (3.5\% fermented oat $+3.5 \%$ nature oat), T4 (5.25\% fermented oat $+1.75 \%$ nature oat), T5 ( $7 \%$ fermented oat). Pigs had access to feed and water ad libitum and their BW and average daily feed intake (ADFI) were measured for each phase throughout the duration of the experiment. During the first phase,the use of $7.5 \%, 11.3 \%$ and $15 \%$ fermented oat to replace nature oat improvedaverage daily gain (ADG) and gain/feed ratio (G/F) $(\mathrm{P}<0.05)$. . During the second phase, the use of $3.5 \%, 5.3 \%$, and $7 \%$ fermented oat to substitute nature increased ADG. Entire period of this experiment, T3 and T4 treatments were presented higher ADG, G/F compared with T1 and T2 treatments. Different levels of fermented oat didnot affect diarrhea incidence score, digestibility, fecal microorganisms and emission gas. It is concluded thatfermented oat can serve as an alternative feed ingredient for possibly replacing the use of nature oat.
\end{abstract}

Keywords: fermented oat, growth, weaning pigs

\section{Introduction}

"Post-weaning check period" is a major problem for the swine industry (Pluske et al., 1997). During this period, pigs are faced with profound environmental and social changes as well as acute changes in nutritional substrate. Those changes result in myriad of stressors, which occur in gut structure and function. They are generally associated with the poor performance observed as they are thought to cause a temporary decrease in digestive and absorptive capacity. Diet formulation would influence gastrointestinal morphology, physiology, and microbiology (Van Beers Schreurs, 1996; Pluske et al., 1997; Jensen \& Mik-kelsen, 1998). Many literatures have revealed that feeding fermented diet to weaning piglets was beneficial for gastrointestinal tract and growth performance. The study conducted by Scholten et al. (2002) revealed that feeding a partly fermented liquid diet to weanling decreased gastric $\mathrm{pH}$, and increased villus height. Renel et al. (2001) demonstrated that a bigger count of total Lactobacilli and a smaller count of E.coli were found in the gastrointestinal tracts, especially, at the front apart of pigs fed fermented feed. Kim et al. (2006) believed that growth performance of pigs is improved by the addition of fermented persimmon shell diet.

Oats are known to have a favorable nutrient content, comprising high levels of polyunsaturated fatty acids, phospholipids, high-quality protein, and fibers as beta-glucans; oats also contain many minerals and vitamins (Webster, 1986; Frolich \& Nyman, 1988). Oatmeal was mixed with water and fermented with Lactobacillus which had not only a beneficial nutritional composition but also contains high numbers of lactobacilli to colonize the intestinal tract and to compete with the resident flora. Molin et al. (1992) reported that Lactobacillus reuteri in fermented oats were able to, effectively, colonized the mucosa of rat. Fermented oat could decrease serum 
cholesterol levels, resulted from lactobacilli are the main contributors to total bile salt hydrolase activity in the murine intestinal tract (Tannock et al., 1989). Fermented oat can change short chain fatty acid formation in the caecum, distal colon and feces of rats. Practically, those changes indicated that these microbes probably survive in the hindgut and led to the modification of the microflora composition (Lambo et al., 2005). It may be important for the gastrointestinal microflora balance in relation to colonic diseases. Fermented oat could increase non-haem iron absorption from a phytate rich meal in healthy women of childbearing age (Bering et al., 2006).

However, there is dearth of information on the influence of fermented oat in weaning pigs. Considering the potential benefits accruable from fermented oat meal, we hypothesized that fermented oat meal is able to ensure a healthy gastrointestinal tracts to increase growth performance. Therefore, this study was conducted to investigate the effects of different levels of fermented oat meal on growth performance, diarrhea incidence, fecal microorganisms, and emission gas in weaned pigs.

\section{Materials and Methods}

All pigs used in this trial were handled in accordance with the guidelines set forth by the Animal Care and Use Committee of Dankook University.

\subsection{Experimental Design, Animals and Diets}

The animal care and use protocol was approved by the Animal Care and Use Committee of Dankook University. A total of 80 crossbred [(Landrace $\times$ Yorkshire $) \times$ Duroc] pigs (average $21 \mathrm{~d}$ ) with an average initial BW of $7.31 \pm$ $0.24 \mathrm{~kg}$ were randomly assigned by $\mathrm{BW}$ and sex in a randomized complete block design. This experiment consisted of two phases. In the first phase (from 0 to $21 \mathrm{~d})$, there were 5 treatments: T1 (15\% nature oat), T2 (3.7\% fermented oat $+11.3 \%$ nature oat), T3 (7.5\% fermented oat $+7.5 \%$ nature oat $)$, T4 $(11.3 \%$ fermented oat $+3.7 \%$ nature oat $)$, T5 (15\% fermented oat). In the second phase (from 21 to $35 \mathrm{~d})$ : T1 (7\% nature oat), T2 (1.75\% fermented oat + $5.25 \%$ nature oat), T3 (3.5\% fermented oat $+3.5 \%$ nature oat), T4 (5.25\% fermented oat $+1.75 \%$ nature oat $)$, T5 ( $7 \%$ fermented oat). There were 4 pigs per pen, and a treatment comprised 4 replications. All pigs were housed in pens $(0.6 \times 1.2 \mathrm{~m})$ with a self-feeder and nipple drinker to allow ad libitum access to enough feed and water throughout the experimental period. Temperature was maintained at $30{ }^{\circ} \mathrm{C}$ and decreased by $1{ }^{\circ} \mathrm{C}$ each week of the experiment. Antibiotics were not used in any experimental diets. Diets were formulated to the same concentrations of lysine, threonine, tryptophan, methionine, metabolic energy (ME), calcium, and phosphorus. Corn and soybean ratios were altered to keep dietary ME concentration the same among treatment diets. Nutrients were provided to meet or exceed the requirements suggested by NRC (1988) (Tables 1 and 2)

Table 1. Formula and chemical composition (as-fed basis) of experiment diets ( 0 to 21 )

\begin{tabular}{crrrrr}
\hline Item & \multicolumn{1}{c}{ T1 } & \multicolumn{1}{c}{ T2 } & \multicolumn{1}{c}{ T3 } & \multicolumn{1}{c}{ T5 } \\
\hline Ingredient, \% & & & & & \\
Corn & 16.11 & 16.51 & 16.91 & 17.11 & 17.51 \\
Nature oat & 15.00 & 11.25 & 7.50 & 3.75 & 0.00 \\
Fermented oat & 0.00 & 3.75 & 7.50 & 11.25 & 15.00 \\
Edible lard & 4.00 & 4.00 & 4.00 & 4.00 & 4.00 \\
Whey proteins & 29.41 & 29.01 & 28.61 & 28.21 & 27.81 \\
Soybean meal (48\%) & 22.15 & 22.15 & 22.15 & 22.15 & 22.15 \\
Fish meal & 8.00 & 8.00 & 8.00 & 8.00 & 8.00 \\
Plasma protein & 4.11 & 4.11 & 4.11 & 4.11 & 4.11 \\
L-LysineHCl & 0.03 & 0.03 & 0.03 & 0.03 & 0.03 \\
DL-Methionine & 0.16 & 0.16 & 0.16 & 0.16 & 0.16 \\
Limestone & 0.17 & 0.17 & 0.17 & 0.17 & 0.17 \\
Dicalcium phosphate & 0.08 & 0.08 & 0.08 & 0.08 & 0.08 \\
Mineral premix ${ }^{\mathrm{a}}$ & 0.50 & 0.50 & 0.50 & 0.50 & 0.50 \\
Copper sulfate & 0.08 & 0.08 & 0.08 & 0.08 & 0.08 \\
Salt & 0.10 & 0.10 & 0.10 & 0.10 & 0.10 \\
Vitamin premix & 0.10 & 0.10 & 0.10 & 0.10 & 0.10 \\
Composition (calculated) & & & & & \\
ME, Mcal/kg & 3.4 & 3.4 & 3.4 & 3.4 & 3.4 \\
Lactose, \% & 20.9 & 20.9 & 20.9 & 20.9 & 20.9 \\
Crude protein, \% & 25.1 & 25.1 & 25.1 & 25.1 & 25.1 \\
Crude fat, \% & 6.4 & 6.4 & 6.4 & 6.4 & 6.4 \\
Crude fibre, \% & 1.66 & 1.66 & 1.65 & 1.65 & 1.64 \\
Crude Ash, \% & 6.77 & 6.77 & 6.77 & 6.77 & 6.77 \\
Lysine, \% & 1.77 & 1.77 & 1.77 & 1.77 & 1.77 \\
Methionine, \% & 0.59 & 0.59 & 0.59 & 0.59 & 0.59 \\
Calcium, \% & 0.80 & 0.80 & 0.80 & 0.80 & 0.80 \\
Phosphorus, \% & 0.83 & 0.83 & 0.83 & 0.83 & 0.83 \\
\hline & & & & &
\end{tabular}

Notes: 
${ }^{1}$ Abbreviation: $\mathrm{T} 1$, basal diet $+15 \%$ nature oat; $\mathrm{T} 2$, basal diet $+3.7 \%$ fermented oat $+11.3 \%$ nature oat; $\mathrm{T} 3$, basal diet $+7.5 \%$ fermented oat $+7.5 \%$ nature oat; $\mathrm{T} 4$, basal diet $+11.3 \%$ fermented oat $+3.7 \%$ nature oat; $\mathrm{T} 5$, basal diet $+15 \%$ fermented oat.

${ }^{a}$ Provided the following (g/kg premix): choline, 60; $\mathrm{Zn}, 23.5 ; \mathrm{Fe}, 20.0 ; \mathrm{K}, 20.0 ; \mathrm{S}, 16.3$ : Ca, 10.0; P, 5.5; $\mathrm{Mn}, 5.0$; $\mathrm{Na}, 2.8 ; \mathrm{Cu}, 1.8 ; \mathrm{Mg}, 1.0 ; \mathrm{I}, 0.4 ; \mathrm{Cl}, 0.4 ; \mathrm{Co}, 0.2 ; \mathrm{Se}, 0.06$.

${ }^{\mathrm{b}}$ Provided the following per kilogram of premix: vitamin A, 33,000,000 IU; vitamin D3, 6,600,000 IU; vitamin E, 55,000 IU; vitamin K, $5.12 \mathrm{~g}$; vitamin C, $117 \mathrm{~g}$; niacin, $33.07 \mathrm{~g}$; pantothenate, $29.98 \mathrm{~g}$; riboflavin,8.38 g; vitamin B6, $4.00 \mathrm{~g}$; folic acid, $2.76 \mathrm{~g}$; thiamin, $2.04 \mathrm{~g}$; biotin $66 \mathrm{mg}$; vitamin B12,44mg.

${ }^{\mathrm{c}}$ Provided the following per kilogram of diet: citric acid, $13.8 \mathrm{~g}$; potassium sorbate, $4.5 \mathrm{~g}$; vitamin E, 66IU; flavor additive, $300 \mathrm{mg}$; Fe, $60 \mathrm{mg}$; Zn, $71 \mathrm{mg}$; Mn, $31 \mathrm{mg}$; flow agent, $7.5 \mathrm{~g}$; (d 0 to 14, liquid diet only); bentonite, $7.5 \mathrm{~g}$ (d 0 to 14 , dry pellet diet only).

Table 2. Formula and chemical composition (as-fed basis) of experiment diets (21 to 35)

\begin{tabular}{|c|c|c|c|c|c|}
\hline Item $^{1}$ & $\mathrm{~T} 1$ & $\mathrm{~T} 2$ & T3 & $\mathrm{T} 4$ & $\mathrm{~T} 5$ \\
\hline \multicolumn{6}{|l|}{ Ingredient, $\%$} \\
\hline Corn & 32.80 & 33.00 & 33.20 & 33.40 & 33.60 \\
\hline Nature oat & 7.00 & 5.25 & 3.50 & 1.75 & 0.00 \\
\hline Fermented oat & 0.00 & 1.75 & 3.50 & 5.25 & 7.00 \\
\hline Edible lard & 4.00 & 4.00 & 4.00 & 4.00 & 4.00 \\
\hline Whey proteins & 22.20 & 22.00 & 21.80 & 21.60 & 21.40 \\
\hline Soybean meal (48\%) & 25.00 & 25.00 & 25.00 & 25.00 & 25.00 \\
\hline Fish meal & 5.05 & 5.05 & 50.5 & 5.05 & 50.5 \\
\hline Plasma protein & 2.00 & 2.00 & 2.00 & 2.00 & 2.00 \\
\hline L-LysineHCl & 0.04 & 0.04 & 0.04 & 0.04 & 0.04 \\
\hline DL-Methionine & 0.12 & 0.12 & 0.12 & 0.12 & 0.12 \\
\hline Limestone & 0.45 & 0.45 & 0.45 & 0.45 & 0.45 \\
\hline Dicalcium phosphate & 0.56 & 0.56 & 0.56 & 0.56 & 0.56 \\
\hline Mineral premix ${ }^{\mathrm{a}}$ & 0.50 & 0.50 & 0.50 & 0.50 & 0.50 \\
\hline Copper sulfate & 0.08 & 0.08 & 0.08 & 0.08 & 0.08 \\
\hline Salt & 0.10 & 0.10 & 0.10 & 0.10 & 0.10 \\
\hline Vitamin premix $^{\mathrm{b}}$ & 0.10 & 0.10 & 0.10 & 0.10 & 0.10 \\
\hline \multicolumn{6}{|l|}{ Composition (calculated) } \\
\hline $\mathrm{ME}, \mathrm{Mcal} / \mathrm{kg}$ & 3.3 & 3.3 & 3.3 & 3.3 & 3.3 \\
\hline Lactose, $\%$ & 15.7 & 15.7 & 15.7 & 15.7 & 15.7 \\
\hline Crude protein, $\%$ & 23.1 & 23.1 & 23.1 & 23.1 & 23.1 \\
\hline Crude fat, $\%$ & 5.9 & 5.9 & 5.9 & 5.9 & 5.9 \\
\hline Crude fibre, $\%$ & 1.91 & 1.91 & 1.91 & 1.91 & 1.91 \\
\hline Crude Ash, \% & 6.17 & 6.17 & 6.17 & 6.17 & 6.17 \\
\hline Lysine, \% & 1.56 & 1.56 & 1.56 & 1.56 & 1.56 \\
\hline Methionine, $\%$ & 0.51 & 0.51 & 0.51 & 0.51 & 0.51 \\
\hline Calcium, \% & 0.80 & 0.80 & 0.80 & 0.80 & 0.80 \\
\hline Phosphorus, \% & 0.76 & 0.76 & 0.76 & 0.76 & 0.76 \\
\hline
\end{tabular}

Notes:

${ }^{1}$ Abbreviation: $\mathrm{T} 1$, basal diet $+7 \%$ nature oat; $\mathrm{T} 2$, basal diet $+1.7 \%$ fermented oat $+5.3 \%$ nature oat; $\mathrm{T} 3$, basal diet $+3.5 \%$ fermented oat $+3.5 \%$ nature oat; $\mathrm{T} 4$, basal diet $+5.3 \%$ fermented oat $+1.7 \%$ nature oat; $\mathrm{T} 5$, basal diet $+7 \%$ fermented oat.

${ }^{\mathrm{a}}$ Provided the following (g/kg premix): choline, 60; $\mathrm{Zn}, 23.5 ; \mathrm{Fe}, 20.0 ; \mathrm{K}, 20.0 ; \mathrm{S}, 16.3: \mathrm{Ca}, 10.0 ; \mathrm{P}$, 5.5; Mn, 5.0; Na, 2.8; Cu, 1.8; Mg, 1.0; I, 0.4; Cl, 0.4; Co, 0.2; Se, 0.06.

b Provided the following per kilogram of premix: vitamin A, 33,000,000 IU; vitamin D3, 6,600,000 IU;vitamin E, 55,000 IU; vitamin K, $5.12 \mathrm{~g}$; vitamin C, $117 \mathrm{~g}$; niacin, $33.07 \mathrm{~g}$; pantothenate, $29.98 \mathrm{~g}$; riboflavin,8.38 g; vitamin B6, $4.00 \mathrm{~g}$; folic acid, $2.76 \mathrm{~g}$; thiamin, $2.04 \mathrm{~g}$; biotin $66 \mathrm{mg}$; vitamin B12,44mg. 


\subsection{Sampling and Measurements}

Individual body weight and feed consumption per pen were measured at the end of each phase of the experiment to monitor the average daily gain (ADG), average daily feed intake (ADFI) and gain: feed ratio (G/F).

Chromium oxide $\left(\mathrm{Cr}_{2} \mathrm{O}_{3}\right)$ was added to each of the diet as an inert indicator $(0.20 \%)$ to calculate the apparent total tract digestibility (ATTD) for dry matter (DM), nitrogen (N) and energy during each dietary phase. After the pigs were fed diet containing the indicator for $5 \mathrm{~d}$, fresh fecal grab samples were obtained from 2 pigs (one barrow and one gilt) per pen. All fecal and feed samples from one pen were then pooled and mixed, after which a representative sample was stored in a freezer at $-20{ }^{\circ} \mathrm{C}$ until analysis. Prior to chemical analysis, the fecal samples were thawed and dried at $70{ }^{\circ} \mathrm{C}$ for $72 \mathrm{~h}$, after which they were finely ground to a size that could pass through a $1 \mathrm{~mm}$ sieve. All of the feed and fecal samples were then analyzed for DM and $\mathrm{N}$ following the procedures outlined by the AOAC (2004). Chromium was analyzed using UV absorption spectrophotometer (Shimadzu, UV-1201, Kyoto, Japan) while nitrogen was determined using a Kjeltec 2300 Analyzer (Foss Tecator AB, Hoeganaes, Sweden). Gross energy was determined by measuring the heat of combustion in the samples using a Parr 6100 oxygen bomb calorimeter (Parr instrument Co., Moline, IL).

For each piglet showing diarrhoea, the severity was assessed visually and characterized, by the same person, according to the following scale as: 0 , normal, firm feces; 1 , possible slight diarrhea; 2 , definitely unformed, moderately fluid feces; or 3, very watery and frothy diarrhea. The total diarrhoea score on a pen basis was calculated as the sum of the number of piglets in the pen with diarrhoea multiplied by the days of observations and multiplied by the diarrhoea scale observed in the majority of the pigs in the pen. Diarrhoea scores were calculated by day. The maximum theoretical diarrhoea score was 16 ( 4 pigs $\times$ scale $4=24)$.

Total bacteria, including Lacobacillus, Bacillus subtilisandEscherichia coli were determined on fresh morning fecal samples at 7, 14, 21, and $28 \mathrm{~d}$ of age. Microbial populations were determined by serial dilution $\left(10^{-1}\right.$ to $10^{-7}$ ) in anaerobic diluents before inoculation onto petri dishes of sterile agar as described by Bryant and Burkey (1953). Lactobacilli were cultured on Rogosa SL agar (DIFCO Laboratories, Detroit, MI). Escherichia coli strains JM83 and DH5a were grown on LB medium (10 g tryptone, $5 \mathrm{~g}$ yeast extract, $5 \mathrm{~g} \mathrm{NaCl}$ per liter), Brain Heart Infusion (BHI) medium (DIFCO), and media supplemented with kanamycin $(50 \mathrm{mg} / \mathrm{ml})$ or erythromycin $(150 \mathrm{mg} / \mathrm{ml}$ in BHI) when selecting for transformants. Bacillus subtiliswere routinely grown on BHI supplemented with tylosin $(10 \mathrm{mg} / \mathrm{ml})$ when selecting for transformants. Strains identified as Lactobacillus species were grown on MRS medium (DIFCO). Potential tylosin/erythromycin resistant strains were grown on media containing $20 \mathrm{mg} / \mathrm{ml}$ of these antibiotics. Inoculating drops of three appropriate dilutions onto their respective plates maximized counting precision of the microbiota. After stored anaerobically at $32^{\circ} \mathrm{C}$ for 48 to 72 $\mathrm{h}$, all plates were counted. Anaerobic conditions were generated using an anaerobic jar with a gas generator envelope (GasPak Plus, disposable $\mathrm{H}_{2}$ and $\mathrm{CO}_{2}$ generating system with palladium catalyst; Fisher Scientific, Pittsburgh, PA). The final anaerobic atmosphere consisted of 6.5 to $7.5 \% \mathrm{CO}_{2}, 25$ to $35 \% \mathrm{H}_{2}$, with the balance being $\mathrm{N}_{2}$.

Fresh feces and urine samples were collected randomly from at least two pigs in each pen every afternoon from day 25 to day 27 by scouting and collection. Samples were kept in sealed containers and were immediately stored at $-4^{\circ} \mathrm{C}$ for the duration of the period. After the collection period, feces and urine samples were pooled and mixed well for each pen, respectively. According to the method of Cho et al. (2008), subsamples of slurry (150 g feces and $150 \mathrm{~g}$ of urine were mixed well, 1:1, wt/wt; wet weight basis) were taken and stored in 2.6-L plastic boxes in duplicate. Thereby, $\mathrm{pH}$ was measured from the middle layer (about $0.5 \mathrm{~cm}$ beneath the surface) of the samples. Averages of $\mathrm{pH}$ were used for statistical analyses. Thereafter plastic boxes were sealed carefully. Each box had a small hole in the middle of one side wall, which was sealed with adhesive plaster. The samples were permitted to ferment for 7 days at room temperature $\left(25^{\circ} \mathrm{C}\right)$. After the fermentation period, a Gastec (Model GV-100) gas sampling pump was utilized for gas detection. Levels of $\mathrm{NH}_{3}, \mathrm{H}_{2} \mathrm{~S}$, mercaptans, acetic, propionic and butyric acids were measured within the scope of 5.0-100.0 (No. 3La, detector tube; Gastec Corp.), 2.0-20.0 (4LK, detector tube; Gastec Corp.), 0.5-120.0 (No. $70 \mathrm{~L}$ and 70, detector tube; Gastec Corp.) and 2.0-50.0 (No.81 L, detector tube; Gastec Corp.) ppm. Prior to the measurements, slurry samples were shaken manually for approximately $30 \mathrm{~s}$ in order to disrupt any crust formation on the surface of the slurry sample and to homogenize them. The adhesive plasters were punctured, and $100 \mathrm{ml}$ of headspace air was sampled approximately $2.0 \mathrm{~cm}$ above the slurry surface.

\subsection{Statistical Analyses}

All experimental data was analyzed in accordance with the GLM Procedure (SAS, 1996). The pen was used as the experimental unit. Differences among treatment means were determined using the Duncan's Multiple Range test. A probability level of $\mathrm{P}<0.05$ was considered to be statistically significant. 


\section{Results}

\subsection{Chemical Composition of Experimental Oats}

The changes in chemical composition between nature and fermented oat are shown in Table 3 . The crude protein of fermented oat was higher than nature oat significantly $(\mathrm{P}<0.05)$. Fermentation decreased dry matter and $\mathrm{pH}$ value of oat $(\mathrm{P}<0.05)$. No difference was observed in the dry matter, crude fiber, crude fat and crude ash $(\mathrm{P}>0.05)$.

Table 3. The change of chemical composition between fermented oat and nature oat

\begin{tabular}{cccc}
\hline Item & Nature oat & Fermented oat & Significance of effects \\
\hline Dry matter & 87.6 & 84.3 & $*$ \\
Crude protein $(\%, \mathrm{DM})$ & 14.7 & 18.3 & $*$ \\
Crude fat (\%,DM) & 5.69 & 5.71 & $\mathrm{NS}$ \\
Crude fiber (\%, DM) & 10.5 & 10.1 & $\mathrm{NS}$ \\
Crude ash (\%, DM) & 3.21 & 3.19 & $\mathrm{NS}$ \\
$\mathrm{pH}$ & 6.93 & 4.87 & $*$ \\
\hline
\end{tabular}

NS: no significant difference, $\mathrm{P}>0.05 ; * \mathrm{P}<0.05$; means differ significantly.

\subsection{Growth Performance}

The effect of different levels of fermented oat on growth performance is presented in Table 4. During the first phase, the use of $7.5 \%, 11.3 \%, 15 \%$ fermented oat to replace nature oat improved ADG and $\mathrm{G} / \mathrm{F}(\mathrm{P}<0.05)$. Pigs fed fermented oat up to $11.3 \%$ exhibited higher $\mathrm{G} / \mathrm{F}$ value than pigs fed fermented oat replaced with $15 \%$ nature oat $(\mathrm{P}<0.05)$. No difference in ADG was observed between T4 and T5 treatments $(\mathrm{P}>0.05)$. During the second phase, the use of fermented oat up to 3.5, 5.3 and 7\% increased ADG $(\mathrm{P}<0.05)$. T3 and T4 showed the highest value of ADG. Throughout the entire period of the experiment, $\mathrm{T} 3$ and $\mathrm{T} 4$ treatments were presented higher ADG, $\mathrm{G} / \mathrm{F}$ compared with $\mathrm{T} 1$ and $\mathrm{T} 2$ treatments $(\mathrm{P}<0.05)$.

Table 4. The effects of different levels of fermented oat on growth performance of weaned pigs ${ }^{1}$

\begin{tabular}{lrrrrrr}
\hline Items & $\mathrm{T} 1$ & $\mathrm{~T} 2$ & $\mathrm{~T} 3$ & $\mathrm{~T} 4$ & $\mathrm{~T} 5$ & $\mathrm{SE}^{2}$ \\
\hline 3- week & & & & & & \\
ADG, g & $351^{\mathrm{b}}$ & $349^{\mathrm{b}}$ & $419^{\mathrm{a}}$ & $393^{\mathrm{ab}}$ & $378^{\mathrm{ab}}$ & 15 \\
ADFI, g & 457 & 440 & 452 & 454 & 471 & 37 \\
Gain:Feed & $0.768^{\mathrm{b}}$ & $0.793^{\mathrm{b}}$ & $0.927^{\mathrm{a}}$ & $0.866^{\mathrm{ab}}$ & $0.803^{\mathrm{b}}$ & 0.036 \\
5- week & & & & & & \\
ADG, g & $521^{\mathrm{b}}$ & $534^{\mathrm{b}}$ & $554^{\mathrm{a}}$ & $556^{\mathrm{a}}$ & $549^{\mathrm{ab}}$ & 12 \\
ADFI, g & 890 & 881 & 878 & 889 & 879 & 46 \\
Gain:Feed & 0.586 & 0.606 & 0.631 & 0.625 & 0.625 & 0.045 \\
Overall & & & & & & \\
ADG, g & $436^{\mathrm{b}}$ & $442^{\mathrm{b}}$ & $487^{\mathrm{a}}$ & $475^{\mathrm{a}}$ & $464^{\mathrm{ab}}$ & 11 \\
ADFI, g & 674 & 661 & 668 & 672 & 675 & 29 \\
Gain:Feed & $0.647^{\mathrm{b}}$ & $0.669^{\mathrm{b}}$ & $0.729^{\mathrm{a}}$ & $0.707^{\mathrm{a}}$ & $0.687^{\mathrm{ab}}$ & 0.033 \\
\hline
\end{tabular}

Notes:

${ }^{1}$ Abbreviation: T1, basal diet $+[15 \%$ nature oat (phase 1), 7\% nature oat (phase 2) $]$; T2, basal diet $+[3.7 \%$ fermented oat $+11.3 \%$ nature oat (phase 1), $1.7 \%$ fermented oat $+5.3 \%$ nature oat (phase 2)]; T3, basal diet + $[7.5 \%$ fermented oat $+7.5 \%$ nature oat (phase 1 ), $3.5 \%$ fermented oat $+3.5 \%$ nature oat (phase 2 )]; T4, basal diet $+[11.3 \%$ fermented oat $+3.7 \%$ nature oat (phase 1$), 5.3 \%$ fermented oat $+1.7 \%$ nature oat (phase 2$)]$; T5, basal diet $+[15 \%$ fermented oat (phase 1$), 7 \%$ fermented oat (phase 2$)]$.

${ }^{2}$ Standard error.

${ }^{\mathrm{a}, \mathrm{b}}$ Means in the same row with different superscripts differ $(P<0.05)$. 


\subsection{Diarrhea Score, Nutrient Digestibility, Fecal Microorganisms, Noxious Gas Emission}

No effects was observed on diarrhea score, nutrient digestibility, fecal microorganisms, noxious gas emission from slurry and volatile fatty acid, when using different levels of fermented oat to substitute nature oat (Tables 5 , 6,7 , and 8).

Table 5. The effects of different levels of fermented oat on diarrhea incidenceand nutrient digestibility of weaning pigs ${ }^{1}$

\begin{tabular}{lcccccl}
\hline Items, \% & $\mathrm{T} 1$ & $\mathrm{~T} 2$ & $\mathrm{~T} 3$ & $\mathrm{~T} 4$ & $\mathrm{~T} 5$ & $\mathrm{SE}^{2}$ \\
\hline $\begin{array}{l}\text { Diarrhea incidence, \% } \\
\text { 3 week }\end{array}$ & 8.0 & 7.6 & 6.2 & 6.8 & 6.8 & 0.358 \\
$\quad$ & & & & & & \\
$\quad$ Dry matter & 80.5 & 80.6 & 82.6 & 82.9 & 81.1 & 1.9 \\
$\quad$ Nitrogen & 78.9 & 80.2 & 80.2 & 79.6 & 80.4 & 1.8 \\
$\quad$ Energy & 79.7 & 80.8 & 80.9 & 81.3 & 79.8 & 1.5 \\
5 week & & & & & & \\
$\quad$ Dry matter & 80.6 & 82.4 & 81.8 & 82.1 & 82.2 & 1.7 \\
$\quad$ Nitrogen & 79.7 & 80.3 & 80.2 & 79.1 & 80.4 & 1.8 \\
$\quad$ Energy & 79.7 & 80.7 & 80.9 & 81.3 & 80.2 & 1.9 \\
\hline
\end{tabular}

Notes:

${ }^{1}$ Abbreviation: T1, basal diet $+[15 \%$ nature oat (phase 1), $7 \%$ nature oat (phase 2) $]$; T2, basal diet $+[3.7 \%$ fermented oat $+11.3 \%$ nature oat (phase 1 ), $1.7 \%$ fermented oat $+5.3 \%$ nature oat (phase 2)]; T3, basal diet + [7.5\% fermented oat $+7.5 \%$ nature oat (phase 1 ), $3.5 \%$ fermented oat $+3.5 \%$ nature oat (phase 2 )]; $\mathrm{T} 4$, basal diet $+[11.3 \%$ fermented oat $+3.7 \%$ nature oat (phase 1$), 5.3 \%$ fermented oat $+1.7 \%$ nature oat (phase 2$)]$; T5, basal diet $+[15 \%$ fermented oat (phase 1$), 7 \%$ fermented oat (phase 2$)]$.

${ }^{2}$ Standard error.

Table 6. The effects of different levels of fermented oat on fecal microorganisms in weaning pigs ${ }^{1}$

\begin{tabular}{lcccccc}
\hline Item, $\log _{10}$ cfu/g & $\mathrm{T} 1$ & $\mathrm{~T} 2$ & $\mathrm{~T} 3$ & $\mathrm{~T} 4$ & $\mathrm{~T} 5$ & $\mathrm{SE}^{2}$ \\
\hline Lactobacillus & & & & & & \\
1 week & 6.5 & 6.4 & 6.5 & 6.4 & 6.6 & 0.6 \\
2 week & 6.9 & 6.6 & 7.1 & 6.7 & 7.0 & 0.5 \\
3 week & 6.9 & 6.6 & 7.4 & 6.9 & 7.0 & 0.6 \\
4 week & 7.0 & 7.1 & 7.6 & 7.4 & 7.2 & 0.6 \\
Bacillus subtilis & & & & & & \\
1 week & 6.1 & 6.5 & 6.4 & 5.8 & 6.5 & 0.6 \\
2 week & 6.0 & 6.6 & 6.6 & 6.2 & 6.0 & 0.9 \\
3 week & 6.5 & 6.5 & 7.0 & 6.4 & 6.3 & 0.7 \\
4 week & 7.2 & 7.4 & 7.2 & 6.6 & 6.8 & 0.6 \\
Escherichia coli & & & & & & \\
1 week & 6.1 & 6.5 & 6.5 & 6.1 & 6.6 & 0.6 \\
2 week & 6.3 & 6.5 & 6.4 & 6.2 & 6.4 & 0.5 \\
3 week & 6.2 & 6.4 & 6.3 & 6.0 & 6.4 & 0.7 \\
4 week & 6.1 & 6.4 & 6.2 & 6.1 & 6.3 & 0.6 \\
\hline
\end{tabular}

Notes:

${ }^{1}$ Abbreviation: T1, basal diet $+[15 \%$ nature oat (phase 1), $7 \%$ nature oat (phase 2) $]$; T2, basal diet $+[3.7 \%$ fermented oat $+11.3 \%$ nature oat (phase 1), $1.7 \%$ fermented oat $+5.3 \%$ nature oat (phase 2)]; T3, basal diet + $[7.5 \%$ fermented oat $+7.5 \%$ nature oat (phase 1 ), $3.5 \%$ fermented oat $+3.5 \%$ nature oat (phase 2 )]; $\mathrm{T} 4$, basal diet $+[11.3 \%$ fermented oat $+3.7 \%$ nature oat (phase 1$), 5.3 \%$ fermented oat $+1.7 \%$ nature oat (phase 2$)]$; T5, basal diet $+[15 \%$ fermented oat (phase 1), $7 \%$ fermented oat (phase 2$)]$.

${ }^{2}$ Standard error. 
Table 7. The effects of different levels of fermented oat on noxious gas emission from slurry in weaning pigs ${ }^{1}$

\begin{tabular}{lrrrrrr}
\hline Item, ppm & $\mathrm{T} 1$ & $\mathrm{~T} 2$ & $\mathrm{~T} 3$ & $\mathrm{~T} 4$ & $\mathrm{~T} 5$ & $\mathrm{SE}^{2}$ \\
\hline $\mathrm{NH}_{3}$ & & & & & & \\
$1 \mathrm{~d}$ & 15.9 & 15.1 & 18.7 & 17.5 & 15.4 & 2.07 \\
$3 \mathrm{~d}$ & 16.4 & 15.9 & 19.7 & 19.0 & 17.1 & 1.85 \\
$5 \mathrm{~d}$ & 18.0 & 19.3 & 20.7 & 17.7 & 18.8 & 2.36 \\
$7 \mathrm{~d}$ & 17.1 & 19.4 & 16.4 & 18.0 & 19.6 & 2.38 \\
$\mathrm{H}_{2} \mathrm{~S}$ & & & & & & \\
$1 \mathrm{~d}$ & $\mathrm{ND}$ & $\mathrm{ND}$ & $\mathrm{ND}$ & $\mathrm{ND}$ & $\mathrm{ND}$ & $\mathrm{ND}$ \\
$3 \mathrm{~d}$ & 13.3 & 11.6 & 14.9 & 13.4 & 14.6 & 2.02 \\
$5 \mathrm{~d}$ & 21.4 & 22.1 & 24.6 & 23.7 & 24.0 & 3.02 \\
$7 \mathrm{~d}$ & 26.1 & 24.9 & 24.1 & 25.4 & 28.0 & 2.76 \\
Total mercaptans & & & & & & \\
$1 \mathrm{~d}$ & 9.6 & 8.7 & 9.3 & 10.3 & 8.0 & 1.31 \\
$3 \mathrm{~d}$ & 24.9 & 25.3 & 26.3 & 23.6 & 22.1 & 3.52 \\
$5 \mathrm{~d}$ & 27.4 & 23.1 & 26.4 & 24.9 & 22.4 & 2.25 \\
$7 \mathrm{~d}$ & 19.4 & 22.9 & 17.7 & 25.0 & 24.0 & 3.22 \\
\hline
\end{tabular}

Notes:

${ }^{1}$ Abbreviation: T1, basal diet $+[15 \%$ nature oat (phase 1), 7\% nature oat (phase 2)]; T2, basal diet $+[3.7 \%$ fermented oat $+11.3 \%$ nature oat (phase 1), $1.7 \%$ fermented oat $+5.3 \%$ nature oat (phase 2)]; T3, basal diet + [7.5\% fermented oat $+7.5 \%$ nature oat (phase 1 ), $3.5 \%$ fermented oat $+3.5 \%$ nature oat (phase 2)]; T4, basal diet $+[11.3 \%$ fermented oat $+3.7 \%$ nature oat (phase 1$), 5.3 \%$ fermented oat $+1.7 \%$ nature oat (phase 2$)]$; T5, basal diet $+[15 \%$ fermented oat (phase 1$), 7 \%$ fermented oat (phase 2$)]$.

${ }^{2}$ Standard error.

Table 8. The effects of different levels of fermented oat on volatile fatty acid emission from slurry in weaning pigs ${ }^{1}$

\begin{tabular}{lcccccc}
\hline Item, ppm & T1 & T2 & T3 & T4 & T5 & SE $^{2}$ \\
\hline Acetic acid & & & & & & \\
1 d & 16.1 & 14.3 & 18.6 & 14.3 & 17.3 & 4.69 \\
3 d & 16.9 & 18.0 & 16.9 & 15.1 & 17.3 & 1.63 \\
5 d & 30.6 & 36.6 & 31.6 & 29.3 & 33.6 & 3.43 \\
7 d & 18.9 & 20.1 & 18.4 & 21.9 & 17.4 & 2.53 \\
Propionic acid & & & & & & \\
1 d & 11.7 & 9.9 & 10.3 & 9.6 & 11.4 & 1.25 \\
3 d & 17.0 & 15.1 & 17.6 & 19.9 & 16.9 & 3.44 \\
5 d & 30.3 & 26.1 & 30.1 & 27.0 & 28.6 & 1.38 \\
7 d & 28.6 & 22.1 & 24.4 & 22.7 & 25.3 & 3.34 \\
Butyric acid & & & & & & \\
1 d & 13.6 & 12.0 & 12.4 & 16.7 & 13.6 & 2.13 \\
3 d & 28.3 & 29.9 & 26.6 & 25.4 & 28.9 & 3.18 \\
5 d & 32.1 & 27.1 & 26.1 & 27.9 & 30.4 & 3.08 \\
7 d & 21.9 & 25.7 & 20.3 & 19.3 & 23.1 & 2.64 \\
\hline
\end{tabular}

Notes:

${ }^{1}$ Abbreviation: T1, basal diet $+[15 \%$ nature oat (phase 1), $7 \%$ nature oat (phase 2) $]$; T2, basal diet $+[3.7 \%$ fermented oat $+11.3 \%$ nature oat (phase 1), $1.7 \%$ fermented oat $+5.3 \%$ nature oat (phase 2)]; T3, basal diet + $[7.5 \%$ fermented oat $+7.5 \%$ nature oat (phase 1 ), $3.5 \%$ fermented oat $+3.5 \%$ nature oat (phase 2 )]; $\mathrm{T} 4$, basal diet $+[11.3 \%$ fermented oat $+3.7 \%$ nature oat (phase 1$), 5.3 \%$ fermented oat $+1.7 \%$ nature oat (phase 2$)]$; T5, basal diet $+[15 \%$ fermented oat (phase 1$), 7 \%$ fermented oat (phase 2$)]$.

${ }^{2}$ Standard error. 


\section{Discussion}

There was a little research to evaluate fermented ingredients. Although the ingredients was different, Vranjes and Wenk (1995) reported that barley fermented by enzyme had a more impact on chick performance than unfermented barley form. Cho et al. (2007) reported that piglets fed fermented soya beans showed increased feed efficiency. The study of Kim et al. (2010) also documented that during nursery pigs at 3 to 7 wk of age, a significant increase of ADG and ADFI were observed in treatments fed fermented soybean meal. Furthermore it can serve as an alternative protein source for possibly replacing the use of dried skim milk and plasma protein. In agreement with most studies, our results revealed that fermented oat could improve growth performance, which maybe associated with thesereasons.

The first reason is that after fermentation, oat meal presented a low $\mathrm{pH}$. Additionally, many of the earlier studies on development of the stomach in the pig (Kidder \& Manners, 1978; Simoes-Nunes, 1982) indicated that acid secretion was not well-developed until the pigs were $2-4$ weeks old. Therefore, it is generally believed that fermented oat could alleviate this condition and decrease gastric $\mathrm{pH}$. At first, some undesirable bacteria for instance, E.coli and Salmonella were inhibited (Nout et al., 1989), and those bacteria released toxic substance such as toxic amines and ammonia (Dierick et al., 1986), which were harmful to the gastrointestinal mucosa (Visek, 1972). Secondly, a low gastric pH could increase the activity of digestive enzyme, especially pepsin (Taylor, 1962). Thirdly, a low gastric $\mathrm{pH}$ reduces the rate of gastric emptying, thereby allowing more time for digestion to occur in the stomach (Mayer, 1994). A low gastric pH would also stimulate the secretionof pancreatic juice and bicarbonate, which could buffer the $\mathrm{pH}$ in the upper part of the small intestine, and provide more digestive enzyme to consume nutrients (Sano et al., 1995).

The second reason was digesta viscosity. Lambo et al. (2005) submitted that minor differences were observed between the contents of proteins and minerals in each cereal group; the maximum viscosity for the oat samples decreased after fermentation while the molecular weights were not significantly affected. To our knowledge, digesta viscosity could increase the gastrointestinal myo-electrical activity, and reduce nutrient diffusion to the mucosa (Cherbut et al., 1990; Schneeman, 1990). Viscosity may affect the proliferation of haemolytic E. coli by trapping the bacteria and the substrates necessary for their growth in the lumen of the intestine. The convective solute movement in digesta is impaired by the viscosity of guar gum (Blackburn et al., 1984). The increased motility index increased intestinal transit time (Cherbut et al., 1990), and altered mixing of digesta could also have favored bacterial colonization in the small intestine. Therefore, we could say that fermented oat was more beneficial for growth than nature oat.

Physical activity might be the third reason. Some literature had observed that NSP-rich diets reduce physical activity of growing-finishing pigs (Schrama et al., 1996 \& 1998) and sows (Brouns \& Edwards, 1994; Matte et al., 1994). Additionally, Brooks and Murray (unpublished data) observed significant differences in the behavior of pigs fed fermented and non-fermented diets. Pigs fed a liquid fermented diet spent more time sleeping or resting than pigs fed a dry diet. Since less energy is used for physical activity, this may be responsible for the higher daily gain when fermented diets are fed. Experimental data suggested that short chain fatty acids (SCFA) produced in the large intestine might be related to physical activity of pigs (Scholten et al., 1999).

When pigs fed a diet with 7.5 and 3.5\% fermented oat (phase 1 and 2) to replace nature oat, adversely influence would be observed. This finding might be attributed to the fact that after fermentation, there was a decrease in the content of beta-glucans (Lambo et al., 2006). Hiss and Sauerwein (2003) have demonstrated that beta-glucans could improve growth performance in weaned pigs, with an increase in ADG and ADFI at the level of $0.03 \%$ beta-glucan. The $\mathrm{pH}$ value of the fermented oat is low enough to impact on the gastrointestinal tract. Biagi et al. (2006) submitted that over 6000 ppm gluconic acid added in basal diets would decrease ADG and ADFI.

It was obvious that the partly fermented diet had ability to change the $\mathrm{pH}$ value and short-chain fatty acid levels of the stomach, whereas in the small intestine almost no difference was observed (Scholten et al., 2002). It is possible that low gastric $\mathrm{pH}$ stimulated the secretion of pancreatic bicarbonate, which can buffer the $\mathrm{pH}$ in the first part of the small intestine. Additionally, Jensen and Mikkelsen (1998) found lower gastric pH and higher gastric lactic acid content in piglets fed a completely fermented compound diet for $14 \mathrm{~d}$; while no difference in gastric $\mathrm{pH}$ was observed. This could have been a reason why no difference in fecal emission gas was found. Another reason might be that only the undissociated form of lactic acid and volatile fatty acids (VFA) can have a bactericidal or bacteriostatic effectwhile the active bacteria affected slurry gas emission. In contrast, Johansson et al. (1998) reported a significant increase in the total fecal concentration of carboxylic acids, acetic acid and 
propionic acid in humans. This is inconsistent with the effect of fermented oat on slurry gas emission. We did not find enough references on the effect of fermented oat on slurry gas emission.

In this study, there was no difference in fecal microorganisms between each treatment. In contrast, Fermented oat-bran was found to increase the growth of lactic acid bacteria in rat experiments (RyhaĖnen, 1996). However, this could be associated with the oat fermented by Lactobacillus acidophilus. Due to the fact that fermented liquid compound diet contained a large amount of Lactobacillus, fermented liquid compound diets have a higher number of lactic acid bacteria than nonfermented liquid compound diets (Scholten et al., 2002). Lactobacillus colonized gastrointestinal tracts and this colonization could be maintained for several weeks without extra supplementation when fed the Lactobacillus GG concentration of $10^{7} \mathrm{cfu} \mathrm{ml}^{-1}$ feed. (Kontula et al., 1998) reported that fermented diets had no ability to influence the number of Lactobacillus in feces of weaning pigs.

In conclusion, fermented oat can serve as an alternative feed ingredient for possibly replacing the use of nature oat.

\section{Acknowledgment}

The authors would like to acknowledge the financial assistance (No. PJ0081212012 of Bio-Green 21 and No. 70007054) provided by the Rural Development Administration and Ministry of Knowledge Economy of Korea.

\section{Reference}

AOAC. (2004). Association of Official Analytical Chemists. Official methods of analysis, vol. 2, 18th edition.

Bering, S., Suchdev, S., Sjoltov, L., Berggren, A., Tetens, I., \& Bukhave, K. (2006). A lactic acid-fermented oat gruel increases non-haem iron absorption from a phytate-rich meal in healthy women of childbearing age. Br. J. Nutr., 96, 1-6. http://dx.doi.org/10.1079/BJN20061683

Biagi, G., Piva, A., Moschini, M., Vezzali, E., \& Roth, F. X. (2006). Effect of gluconic acid on piglet growth performance, intestinal microflora, and intestinal wall morphology. J. Anim, Sci., 84, 370-378.

Blackburn, N. A., Redfern, J. S., Jargis, H., Holgate, A. M., Hanning, I., Scarpello, J. H., ... Read, N. W. (1984). The mechanism of action of guar gum in improving glucose tolerance in man. Clinical Sci., 66, 329-336.

Brouns, F., \& Edwards, S. A. (1994). Effect of dietary fibre and feeding system on activity and oral behaviour of group housed gilts. Appl. Anim. Behav. Sci., 39, 215. http://dx.doi.org/10.1016/0168-1591(94)90157-0

Bryant, M. P., \& Burkey, L. A. (1953). Cultural methods and some characteristics of some of the more numerous groups of bacteria in the bovine rumen. J. Dary Sci., 36, 205-217. http://dx.doi.org/10.3168/jds.S0022-0302(53)91482-9

Cherbut, C., Albina, E., Champ, M., Doublier, J. L., \& Lecannu, G. (1990). Action of guar gums on the viscosity of digestive contents and on the gastrointestinal motor function in pigs. Digestion, 46, 205-213. http://dx.doi.org/10.1159/000200347

Cho, J. H., Chen, Y. J., Min, B. J., Yoo, J. S., Wang, Y., \& Kim, I. H. (2008). Effects of reducing dietary crude protein on growth performance, odor gas emission from manure and blood urea nitrogen and IGF-1 concentrations of serum in nursery pigs. Asian-Aust. J. Anim. Sci, 79, 453-459. http://dx.doi.org/10.1111/j.1740-0929.2008.00549.x

Cho, J. H., Min, B. J., Chen, Y. J., Yoo, J. S., Wang, Q., Kim, J. D., \& Kim, I. H. (2007). Evaluation of ESP (fermented soy protein) to replace soybeal meal in weaned pigs: growth performance, blood urea nitrogen and total protein concentrations in serum and nutrient digestibility. Asian-Aust. J. Anim. Sci., 20, 1874-1879.

Dierick, N. A, Vervaeke, I. J. Decuypere, J. A., \& Henderickx, H. K. (1986a). Influence of the gut flora and of somegrowth-promoting feed additives on nitrogen metabolism in pigs. I. Studies in vitro. Livest. Prod. Sci., 14, 161-176. http://dx.doi.org/10.1016/0301-6226(86)90005-9

Frolich, W., \& Nyman, M. (1988). Minerals, phylate and dietaryfiber in different fractions of oat grain. J. Cereal. Sci., 7, 73-82. http://dx.doi.org/10.1016/S0733-5210(88)80061-4

Hiss, S., \& Sauerwein, H. (2003). Influence of dietary ß-glucan on growth performance, lymphocyte proliferation, specific immune response and haptoglobin plasma concentrations in pigs. J. Anim. Physiol An. N., 87, 2-11. http://dx.doi.org/10.1046/j.1439-0396.2003.00376.x

Jensen, B. B., \& Mikkelsen, L. L. (1998). Feeding liquid diets to pigs. (eds P. C. Garnsworthy and J. Wiseman). Nottingham University Press, Loughborough. Recent Advances in Animal Nutrition. U.K., 107-126. 
Johansson, M. L., Nobaek, S., Berggren, A., Nyman, Bjorck, M., Ahrne, I. S., Jeppsson, B., \& Molin, G. (1998).Survival of Lactobacillus plantarum DSM $9843(299 \mathrm{v})$, \& effect on the short-chain fatty acid content of faeces after ingestion of a rose-hip drink with fermented oats. Int. J. Food. Microbiol, 42, 29-38. http://dx.doi.org/10.1016/S0168-1605(98)00055-5

Kidder, D. E., \& Manners, M. J. (1978). Digestion in the Pig. Bristol: ScientechnicSimoes-Nunes, C. (eds P. Laplace, T. Corring and A. Rerat). (J). Paris: INRA. In Digestive Physiology in the Pig, 133-151.

Kim, H. Y., Song, Y. M., Kang, Y. S., Kim, C. H., Lee, S. D., Chowdappa, R., Ha, J. H., \& Kang, S. M. (2006). The effect of fermented persimmon shell diet supplementation on the growth performance and blood parameters in finishing pigs. Anim. Sci, 77, 314-331. http://dx.doi.org/10.1111/j.1740-0929.2006.00354.x

Kim, H. Y., Song, Y. M., Kang, Y. S., Kim, C. H., Lee, S. D., Chowdappa, R., ... Kang, S. M. (2006). The effect of fermented persimmon shell diet supplementation on the growth performance and blood parameters in finishing pigs. J. Anim. Sci, 77, 314-331. http://dx.doi.org/10.1111/j.1740-0929.2006.00354.x

Kim, S. W., van Heugten, E., Ji, F., Lee, C. H., \& Mateo, R. D. (2010). Fermented soybean meal as a vegetable protein source for nursery pigs: I. Effects on growth performance of nursery pigs. J. Anim. Sci, 88, 1214-224. http://dx.doi.org/10.2527/jas.2009-1993

Kontula, P., Jaskari, J., Nollet, L., De-Smet, I., von-Wright, A., Poutanen, K., \& MattilSandholm, T. (1998). The colonization of a simulator of the human intestinal microbial ecosystem by a probiotic strain fed on a fermented oat bran product: effects on the gastrointestinal microbiota. Appl. Microbiol. Biot, 50, 246-252. http://dx.doi.org/10.1007/s002530051284

Lambo, A. M., Rickard, O., Margareta, E. G. L., \& Nyman. (2005). Dietary fibre in fermented oat and barley beta-glucan rich concentrates. J. Agr. Food Chem, 89, 283-293. http://dx.doi.org/10.1016/j.foodchem.2004.02.035

Lambo, A. M., Rickard, O., Margareta, E. G. L., \& Nyman. (2006). Short-chain fatty acid formation in the hindgut of rats fed nativeand fermented oat fibre concentrates. Brit. J. Nurt, 96, 47-55. http://dx.doi.org/10.1079/BJN20061797

Matte, J. J., Robert, S., Girard, C. L., Farmer, C., \& Martineau, G. P. (1994). Effect of bulky diets based on wheat bran or oat hulls on reproductive performance of sows during their first two parities. J. Anim. Sci, 72, 1754-1760.

Mayer, E. A. (1994). The physiology of gastric storage and emptying., Physiology of the Gastrointestinal Tract(eds LR Johnson, DH Alpers, J Christensen, ED Jacobson and JH Walsh). Raven Press, New York, US. 3rd ed., 1, 929-976.

Molin, G., Andersson, R., Ahrne, C., Lommer, I., Johansson, M. L., Jeppsson, B. J., \& Bengmark, S. (1992). Effect of fermented oatmeal soup on cholesterol level and the lactobacillus colonization of rat intestinal mucosa. Antonie van leeuwenhoek, 61, 167-173. http://dx.doi.org/10.1007/BF00584223

Nout, M. J. R., Rombouts, F. M., \& Havelaar, A. (1989). Effect of accelerated natural lactic fermentation of infant food ingredients on some pathogenic microorganisms. Int. J. Food. Mocrobiol, 8, 351-361. http://dx.doi.org/10.1016/0168-1605(89)90006-8

NRC. (1998). Nutrient Requirements of Swine (10th Ed). Washington, DC , National Academy Press.

Pluske, J. R., Hampson, D. J., \& Williams, I. H. (1997). Factors influencing the structure and function of the small intestine in the weaned pig: A review. Livest. Prod. Sci., 51, 215-236. http://dx.doi.org/10.1016/S0301-6226(97)00057-2

Renel, V. W., Bert, A. P., Urlings, L., Snijders, J. L., Keuzenkamp, A. L., J. O. S., \& Frans, V. K. (2001). Effect of fermented feed on the microbial population of the gastrointestinal tracts of pigs. Appl. Environ. Microb, 6, 3071-3076.

RyhaÈnen, E. L. (1996). Studies on probiotic bacterial supplementation in rats fed different diets with special reference to dietary ber. J. Finn. Dairy Sci., 52, 136.

Sano, H., Nakmura, E., Takahashi, H., \& Terashima, Y. (1995). Plasma insulin and glucagon responses to acute challenges of acetate, propionate, n-butyrate and glucose in growing gilts (Susscrofa). Comp. Biochem. Phys. A, 110, 375-378. http://dx.doi.org/10.1016/0300-9629(94)00155-M

SAS. (1998). SAS User's Guide: Statistics. Version 7.0 ed. SAS Institute Inc. Cary CON. USA. 
Schneeman, B. O. (1990). Macronutrient absorption in dietary fibrechemistry,physiology \& health effects. (eds D Kritchevsky, C. Bonfield and J. W. Anderson) (PP. 157-165). New York, Plenum Press. http://dx.doi.org/10.1007/978-1-4613-0519-4_10

Scholten, R. H. J., van der Peet-Schwering, C. M., den Hartog, L. A., Balk, M., \& Schrama Verstegen, J. W. M. W. (2002). Fermented wheat in liquid diets: effects on gastrointestinal characteristics in weanling piglets. $J$. Anim. Sci., 80, 1179-1186. http://dx.doi.org/10.1016/S0377-8401(99)00096-6

Scholten, R. H. J., van der Peet-Schweringa, C. M. C., Verstegenb, M. W. A., den Hartoga, L. A., Schramab, J. W. C., \& Vesseura, P. C. (1999). Fermented co-products and fermented compound diets for pigs: a review. Anim. Feed. Sci. Tech, 82, 1-19.

Schrama, J. W., Bosch, M. W., Verstegen, M. W. A., Vorselaars, A. H. P. M., Haaksma, J., \& Heetkamp, M. J. W. (1998). The energetic value of nonstarch polysaccharides in relation to physical activity in group-housed, growing pigs. Anim. Feed. Sci. Tech, 76, 3016-3023.

Schrama, J. W., Verstegen, M. W. A., Verboeket, P. H. J., Schutte, J. B., \& Haaksma, J. (1996). Energy metabolism in relation to physical activity in growing pigs as affected by type of dietary carbohydrate. $J$. Anim. Sci., 74, 2220-2225.

Simoes-Nunes, C. (1982). In Digestive Physiology in the Pig. (eds T Laplace, Corring and A. Rerat), Paris: INRA,133-151.

Tannock, G. W., Dashkevicz, M. P., \& Feighner, S. D. (1989). Lactobacilli and bile salt hydrolase in murine intestinal tract. App. Environ. Microb, 55, 1848-1851.

Taylor, W. H. (1962). Proteinases of the stomach in health and disease. Physiol. Rev, 42, 519-553.

Van Beers-Schreurs, H. G. M. (1996). The changes in the function of the large intestine of weaned pigs. Ph.D. thesis. Univ. of Utrecht, The Netherlands.

Visek, W. J. (1972). Effects of urea hydrolysis on cell life-span and metabolism. Federation of American Socies for Experimental Biology, 31, 1178-1193.

Vranjes, M. V., \& Wenk, C. (1995). The influence of extruded vs. untreated barley in the feed, with and without dietary enzyme supplement on broiler performance. Anim. Feed Sci. Tech, 54, 21-32. http://dx.doi.org/10.1016/0377-8401(95)00779-M

Webster, F. H. (1986). Chemistry and technology. AmericanAssociation of Cereal Chemists, Inc., St. Paul, MN. 